\title{
Further Observations on Serum Proteins in Respiratory Distress Syndrome of the Newborn
}

\author{
GWENDOLINE HARDIE, V. C. HARRISON, AND J. E. KENCH ${ }^{\star}$ \\ From the Departments of Physiology, Child Health, and Chemical Pathology, \\ University of Cape Town, South Africa
}

In our initial study of newborn infants suffering from the respiratory distress syndrome (RDS) (Hardie, Heese, and Kench, 1965), it was found that affected infants had significantly lower serum concentrations of total proteins than normal premature infants, and that the relative and absolute concentrations of $\gamma$-globulins, as determined by paper electrophoresis, were much diminished. These abnormalities were present in the cord blood and became more marked in the first 2 to 3 days.

In that paper we suggested that the $\gamma$-globulin deficiency could be due to either (1) defective placental transfer of $\gamma$-globulins, or (2) excessive $\gamma$-globulin katabolism by the affected fetus and newborn, or (3) an immune reaction taking place in the fetus and newborn involving the maternal $\gamma$-globulins as either antibodies or antigens.

With these possibilities in mind a more detailed and extensive investigation of the serum proteins in this condition is described.

\section{Clinical Material and Methods}

Subjects of the study were either normal premature infants or premature babies suffering from RDS. The mean gestational age of the normal premature infants for whom data were available (72 of the 88 in the series) was 33.9 weeks. All the RDS infants (33) were traced, and these had a mean gestational age of $35 \cdot 2$ weeks. The clinical criteria for diagnosis of RDS were as before (Hardie et al., 1965). They were the presence of at least two of the following features for which no other obvious cause could be found: (1) cyanosis; (2) rib recession; (3) expiratory grunting; (4) generalized oedema; and (5) a 'ground glass' opacity on $x$-ray of the lung fields with an air bronchogram.

Where the patient presented with cyanosis and

Received February 20, 1968.

$\star$ Requests for reprints should be addressed to Professor J. E. Kench, C.S.I.R. Protein Research Unit, Department of Chemical Pathology, Medical School, University of Cape Town. oedema, it was established that cyanosis was not due to any cause other than respiratory.

Specimens of blood were collected, as previously reported, from the umbilical cord at birth, and from a peripheral vein or a catheter in the umbilical vein on each of the first 3 days after birth, and again between the 4th-10th days. Where possible, follow-up specimens from infants were examined between the ages of 3 weeks and 2 months. Sera were also obtained by cardiac puncture from a small number of fetuses at hysterotomy.

24-hourly specimens of urine were obtained from normal and affected infants. Urine was dialysed, lyophilized, and the residue redissolved in a small volume of $0.15 \mathrm{M} \mathrm{NaCl}$. Meconium and faeces were homogenized in water, centrifuged, and the deposit discarded. The extracts were examined for $\gamma$-globulins by electrophoresis on cellulose acetate, and quantitation of the protein fractions was performed as previously described (Hardie and Kench, 1967). The standard curve for recovery of known quantities of $\gamma$-globulins added to the cellulose acetate strip is shown in Fig. 1.

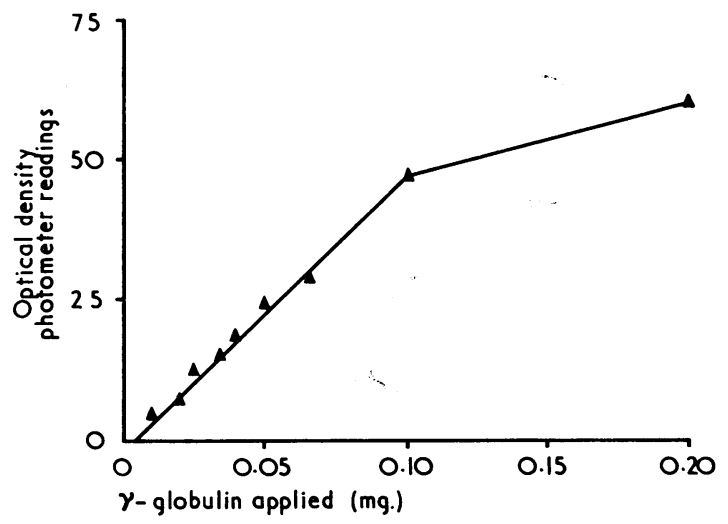

FIG. 1.-Standard curve for recovery of known quantities of $\gamma$-globulins applied to the cellulose acetate strip, and subjected to electrophoresis, staining, and extraction in the usual way. 
TABLE I

Concentrations of Serum Proteins in Normal Premature Infants and in Infants with $R D S$ at Birth and in First 2 months of Life (electrophoretic readings \pm standard deviation)

\begin{tabular}{|c|c|c|c|c|c|c|}
\hline \multirow{2}{*}{ Group } & \multirow{2}{*}{ Age } & \multirow{2}{*}{ No. } & \multirow{2}{*}{$\begin{array}{c}\text { Total } \\
\text { Protein } \\
(\mathrm{g} . / 100 \mathrm{ml} .)\end{array}$} & \multirow{2}{*}{$\underset{(\mathrm{g} . / 100 \mathrm{ml} .)}{\text { Albumin }}$} & \multicolumn{2}{|c|}{$\gamma$-globulin } \\
\hline & & & & & (g. $/ 100 \mathrm{ml})$. & $\begin{array}{l}\text { (\% of total } \\
\text { protein) }\end{array}$ \\
\hline RDS & $\begin{array}{c}\text { Cord } \\
\text { 1st day } \\
\text { 2nd day } \\
\text { 3rd day } \\
\text { 4th-10th day } \\
\text { Later (3 wk. }-2 \text { mth.) }\end{array}$ & $\begin{array}{r}33 \\
33 \\
17 \\
14 \\
14 \\
8\end{array}$ & $\begin{array}{l}3 \cdot 6 \pm 0 \cdot 5 \\
3 \cdot 7 \pm 0 \cdot 6 \\
3 \cdot 6 \pm 0 \cdot 6 \\
3 \cdot 7 \pm 0 \cdot 8 \\
4 \cdot 0 \pm 1 \cdot 0 \\
4 \cdot 4 \pm 0 \cdot 9\end{array}$ & $\begin{array}{l}2 \cdot 76 \pm 0 \cdot 19 \\
2 \cdot 73 \pm 0 \cdot 27 \\
2 \cdot 60 \pm 0 \cdot 23 \\
2 \cdot 68 \pm 0 \cdot 23 \\
2 \cdot 95 \pm 0 \cdot 25 \\
3 \cdot 13 \pm 0 \cdot 29\end{array}$ & $\begin{array}{l}0 \cdot 37 \pm 0 \cdot 10 \\
0 \cdot 38 \pm 0 \cdot 11 \\
0 \cdot 32 \pm 0 \cdot 14 \\
0 \cdot 35 \pm 0 \cdot 12 \\
0 \cdot 40 \pm 0 \cdot 13 \\
0 \cdot 45 \pm 0 \cdot 10\end{array}$ & $\begin{array}{r}10 \cdot 3 \pm 2 \cdot 0 \\
10 \cdot 3 \pm 2 \cdot 5 \\
9 \cdot 1 \pm 2 \cdot 1 \\
9 \cdot 5 \pm 2 \cdot 2 \\
10 \cdot 0 \pm 2 \cdot 2 \\
10 \cdot 2 \pm 2 \cdot 6\end{array}$ \\
\hline Normal premature infants & $\begin{array}{c}\text { Cord } \\
\text { 1st day } \\
\text { 2nd day } \\
\text { 3rd day } \\
\text { 4th-10th day }\end{array}$ & $\begin{array}{l}88 \\
19 \\
16 \\
17 \\
15\end{array}$ & $\begin{array}{l}5 \cdot 4 \pm 0 \cdot 8 \\
5 \cdot 4 \pm 0 \cdot 8 \\
5 \cdot 3 \pm 0 \cdot 7 \\
5 \cdot 1 \pm 0 \cdot 8 \\
5 \cdot 1 \pm 0 \cdot 7\end{array}$ & $\begin{array}{l}3 \cdot 61 \pm 0 \cdot 25 \\
3 \cdot 56 \pm 0 \cdot 27 \\
3 \cdot 55 \pm 0 \cdot 23 \\
3 \cdot 49 \pm 0 \cdot 23 \\
3 \cdot 49 \pm 0 \cdot 21\end{array}$ & $\begin{array}{l}0 \cdot 82 \pm 0 \cdot 15 \\
0 \cdot 78 \pm 0 \cdot 16 \\
0 \cdot 76 \pm 0 \cdot 14 \\
0 \cdot 73 \pm 0 \cdot 13 \\
0 \cdot 72 \pm 0 \cdot 15\end{array}$ & $\begin{array}{l}15 \cdot 1 \pm 2 \cdot 7 \\
14 \cdot 4 \pm 3 \cdot 0 \\
14 \cdot 4 \pm 2 \cdot 5 \\
14 \cdot 4 \pm 2 \cdot 5 \\
14 \cdot 3 \pm 3 \cdot 1\end{array}$ \\
\hline
\end{tabular}

All observations of unknown concentrations of $\gamma$ globulins lie on the linear part of the standard curve. The intercept on the abscissa is due to a small quantity of dyed protein firmly bound to the strip and not extractable by the solvent $(9: 1 \mathrm{v} / \mathrm{v}$ chloroform/ethanol).

In a number of cases, the concentrations of the three main types of immunoglobulin (IgG, IgM, and IgA) were individually determined in the sera and also in the extracts of urine, meconium, and faeces, using immunoplates (Hyland Laboratories).

Column chromatography on dextran gel (Sephadex G200) with $0.1 \mathrm{M}$ tris buffer $p \mathrm{H} \mathrm{8.0}$ and a flow rate of $20 \mathrm{ml}$./hr. was performed on sera of cord blood of 6 affected infants and 6 normal premature infants.

\section{Results}

Findings on the serum are summarized in Tables I and II. Normal infants had a slight steady fall in the concentrations of all protein fractions during the first 3 days of life. The $\gamma$-globulins formed a relatively constant proportion (14-15\%) of the total.

In infants with RDS the concentrations of all protein fractions were lower than normal, all differences being highly significant $(p<0.01)$. The $\gamma$-globulins accounted for a significantly lower proportion (9-10\%) of the total. On the average the $\gamma$-globulin concentrations reached their lowest concentrations during the 2nd to 3rd day of life, and rose slightly thereafter. This was not so with normal infants.

Immunoplate readings were obtained on a smaller number of patients suffering from RDS. As a rule IgG concentrations measured by this method were higher than electrophoretic readings but followed the same general pattern. IgM was always present in measurable quantities in the cord blood, though then, as later, there was a wide scatter in the observed concentrations. Levels had roughly doubled 2 months after birth.

In normal infants only the cord blood was studied by the immunoplate method. The IgG levels were significantly higher than in affected infants $(p<0.01)$ but there was no significant difference in $\operatorname{IgM}$ concentration. $\operatorname{IgM}$ was not invariably present in measurable quantities in the cord blood of normal infants. None of the cord sera contained IgA in measurable amounts. Gel filtration of the sera on Sephadex G200 indicated a smaller area of the $7 \mathrm{~S}$ peak in infants with RDS as compared with normals.

On inspection of the electrophoretic strips it was observed that as a rule sera of infants with RDS contained a protein, generally of low concentration, and migrating between the albumin and $\alpha_{1}$-globulins (Fig. 2). This was not usually present in sera of

\section{TABLE II}

Concentrations of IgG and IgM in Normal Premature Infants at Birth and in Infants with RDS at Birth and During First 2 months of Life (Immunoplate readings \pm standard deviation)

\begin{tabular}{|c|c|c|c|c|}
\hline Group & Age & No. & $\begin{array}{c}\text { IgG } \\
(\mathrm{g} . / 100 \mathrm{ml} .)\end{array}$ & $\begin{array}{c}\operatorname{IgM}(\mathrm{mg} . ! \\
100 \mathrm{ml} .)\end{array}$ \\
\hline RDS & $\begin{array}{c}\text { Cord } \\
\text { 1st day } \\
\text { 2nd day } \\
\text { 3rd day } \\
\text { 4th-10th day } \\
\text { Later }\end{array}$ & $\begin{array}{r}15 \\
11 \\
5 \\
5 \\
10 \\
5\end{array}$ & $\begin{array}{l}0.51 \pm 0.15 \\
0.54 \pm 0.15 \\
0.54 \pm 0.06 \\
0.44 \pm 0.15 \\
0.57 \pm 0.12 \\
0.49 \pm 0.11\end{array}$ & $\begin{array}{l}11 \pm 10 \\
16 \pm 5 \\
16 \pm 4 \\
10 \pm 6 \\
22 \pm 10 \\
34 \pm 7\end{array}$ \\
\hline $\begin{array}{l}\text { Normal } \\
\text { premature } \\
\text { infants }\end{array}$ & Cord & 17 & $0 \cdot 87 \pm 0 \cdot 21$ & $9 \pm 7$ \\
\hline
\end{tabular}




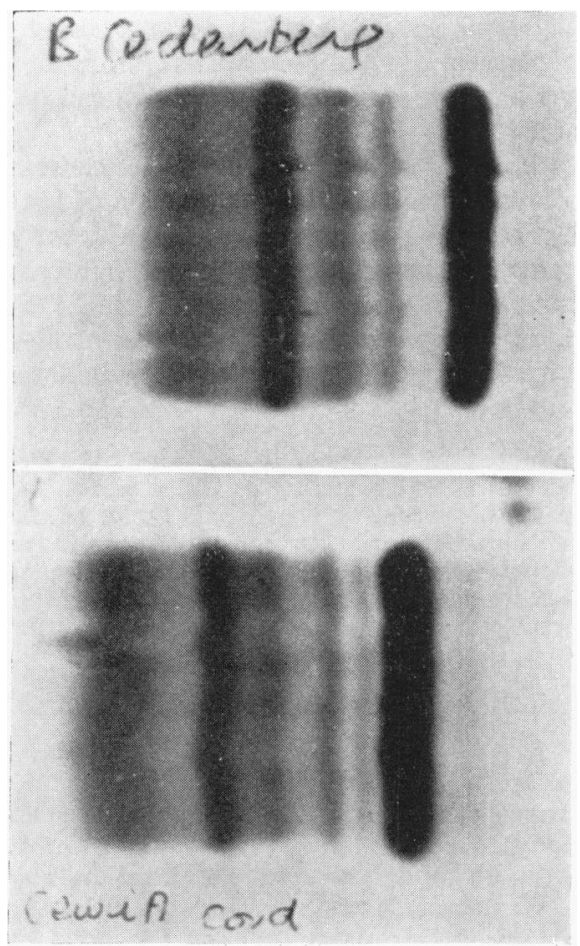

FIG. 2.-Electrophoretic strip of serum of an infant with RDS (below) compared with the serum of a normal premature infant. The serum of the affected infant shows the presence of an $\alpha$-fetoprotein band, immediately adjacent to the prominent albumin band.

normal premature infants. Thus, of 49 cord sera of infants with RDS, it was observed in 43 , while of 48 cord sera of normal premature infants it was seen in only 13. Further, in 4 sets of twins, in each of which only one twin had RDS the other being normal, it was detectable in the serum of the affected twin alone in 3 cases (Fig. 3). In the 4th set this post-albumin fraction was seen in both twins.

The band tended to grow fainter during the first days of life and was usually no longer apparent by 7-8 days of age.

The fetal sera were from fetuses ranging in maturity from 14-22 weeks. A protein migrating in a similar position was observed in all these sera, the intensity of its band being greater in the less mature fetuses.
No difference could be detected between the urinary proteins of normal and affected infants. Meconium and stools were likewise found to contain similar quantities of $\gamma$-globulins.

\section{Discussion}

In our previous study (Hardie et al., 1965), we compared the concentrations of serum proteins of infants suffering from RDS with those of normal premature babies, matched according to birthweight and to age (hours) after birth. The mean concentrations of $\gamma$-globulins were considerably lower in distressed infants of all weight groups than in the comparable group of normal infants; this difference was highly significant $(p<0 \cdot 001)$. H. de V. Heese (personal communication, 1967) found that the birthweight/gestational age ratio of RDS babies was less than that of normal prematures, so probably our RDS patients were relatively older than normal premature infants of the same size at birth. In the larger series now reported, the mean gestational age of the infants with RDS ( $35 \cdot 2$ weeks) was slightly greater than that of the normal premature

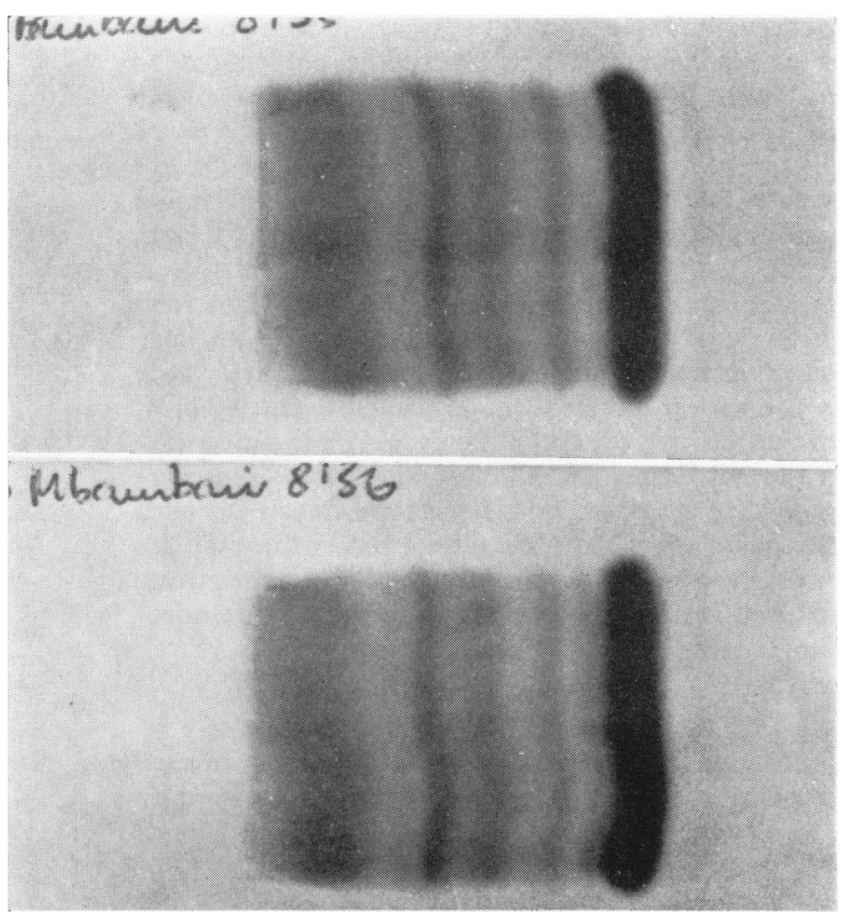

FIG. 3.-Electrophoretic strips of sera of a pair of twins of which one had RDS and the other was clinically normal. The serum of the affected twin (below) shows the presence of an $\alpha$-fetoprotein band, adjacent to the albumin band. 
infants (33.9 weeks). The electrophoretic and immunochemical determinations of the serum proteins have confirmed our earlier observations, and have shown that the deficiency was one of IgG. The finding of a lowered $7 \mathrm{~S}$ peak on gel filtration of the sera supported this. We have attempted to exclude the possibility that abnormally large quantities of protein and particularly $\gamma$-globulins were being lost through the kidneys or alimentary canal. The $\gamma$-globulin present in the meconium and stools of both normal and affected infants was not identical antigenically with IgG and was probably the copro-antibody described by Roulet and von Muralt (1961) and Lipton and Steigman (1957).

The observed low concentrations of serum albumin in RDS subjects may have arisen, partly at least, by leakage through the capillary walls into the oedema fluid which had a high protein content $(1 \cdot 0-2 \cdot 5 \mathrm{~g} . / 100 \mathrm{ml}$.), most of which was albumin. However, this mechanism cannot be held responsible for the deficiency of IgG, which seems likely to be due to defective placental transfer or to some reaction occurring in the fetal and neonatal circulation or tissues. This may be an immune reaction involving the maternal IgG either as an antibody or as an antigen. Such a reaction could cause the generalized capillary lesion which is a feature of the condition. The capillary lesion is unlikely to be anoxic in origin, as, in the lung, the capillary endothelial cells are damaged whereas the alveolar endothelial cells are frequently normal (Strang, 1966).

In contrast to the findings of Gitlin and Boesman (1966) and Bergstrand and Czar (1957) we have detected the presence of the $\alpha$-fetoprotein not only in the sera of fetuses but also in the sera of most infants with RDS, and in an appreciable proportion of normal premature infants, some of whom were as mature as 36 weeks. It was present in the cord blood and even for a few days after birth. We are as yet unable to offer any explanation for the strong association of RDS with the presence of $\alpha$-fetoprotein in the serum of affected infants.

\section{Summary}

Proteins in the serum, urine, and faeces of normal premature infants were compared with those of infants with respiratory distress syndrome (RDS) using electrophoresis on cellulose acetate, immunoplates, and column chromatography on dextran gel (Sephadex G200).

Infants with RDS had abnormally low concentrations of all serum proteins. The proportion of IgG relative to the other serum proteins was significantly less than normal. The presence of an $\alpha$-fetoprotein in the serum was strongly associated with RDS. The protein content of urine and faeces was similar in infants with RDS and normal premature infants.

We are indebted to Professor F. J. Ford and Dr. H. de V. Heese of the Department of Child Health for their interest in this work, to Dr. M. C. Botha of the Blood Transfusion Service for permitting us to make use of his samples, to Miss S. van Olm of the Department of Bacteriology for providing fetal sera, and to Dr. J. G. Burger, Superintendent of Groote Schuur Hospital, for permission to publish.

\section{Addendum}

In a recent study, McKay, Thom, and Gray (1968) have been unable to detect significant differences between the concentrations of $\operatorname{IgG}, \operatorname{IgA}, \operatorname{IgM}$, and albumin in the umbilical cord plasma of healthy infants and of neonates who developed respiratory distress syndrome. The reasons for the disagreement between McKay et al. and ourselves on this issue are not yet apparent.

\section{REFERENCES}

Bergstrand, C. G., and Czar, B. (1957). Paper electrophoretic study of human fetal serum proteins with demonstration of a new protein fraction. Scand. F. clin. Lab. Invest., 9, 277.

Gitlin, D., and Boesman, M. (1966). Serum $\alpha$-fetoprotein, albumin, and $\gamma \mathrm{G}-$ globulin in the human conceptus. $\mathcal{F}$. clin. Invest., 45, 1826.

Hardie, G., Heese, H. de V., and Kench, J. E. (1965). Serumproteins in the idiopathic respiratory-distress syndrome of the newborn. Lancet, $2,876$.

- and Kench, J. E. (1967). Maternal serum-proteins in idiopathic respiratory distress syndrome of the newborn. ibid., $1,809$.

Lipton, M. M., and Steigman, A. J. (1957). Occurrence of $\gamma-$ globulin in human feces. Amer. F. Dis. Child., 93, 39.

McKay, E., Thom, H., and Gray, D. (1968). Immunoglobulins in umbilical cord plasma. III. Haemolytic disease of the newborn and respiratory distress syndrome. Arch. Dis. Childh., 43, 161.

Roulet, D. L. A., and von Muralt, G. (1961). Antigenanalytische Untersuchungen an Fruchtwasser und meconiumproteinen. Schweiz. med. Wschr., 91, 74.

Strang, L. B. (1966). The pulmonary circulation in the respiratory distress syndrome. Pediat. Clin. N. Amer., 13693. 